\title{
Interfacial Water Ordering Is Insufficient to Explain Ice-Nucleating Protein Activity
}

\author{
Max Lukas, ${ }^{*}{ }^{\perp}$ Ralph Schwidetzky, ${ }^{\perp}$ Anna T. Kunert, Ellen H.G. Backus, Ulrich Pöschl, \\ Janine Fröhlich-Nowoisky, Mischa Bonn, and Konrad Meister*
}

Cite This: J. Phys. Chem. Lett. 2021, 12, 218-223

Read Online

ACCESS

Llll Metrics \& More

Article Recommendations

Supporting Information

ABSTRACT: Ice-nucleating proteins (INPs) found in bacteria are the most effective ice nucleators known, enabling the crystallization of water at temperatures close to $0{ }^{\circ} \mathrm{C}$. Although their function has been known for decades, the underlying mechanism is still under debate. Here, we show that INPs from Pseudomonas syringae in aqueous solution exhibit a defined solution structure and show no significant conformational changes upon cooling. In contrast, irreversible structural changes are observed upon heating to temperatures exceeding $\sim 55{ }^{\circ} \mathrm{C}$, leading to a loss of the ice-nucleation activity. Sum-frequency generation (SFG) spectroscopy reveals that active and heat-inactivated INPs impose similar structural ordering of interfacial water molecules upon cooling. Our results demonstrate that increased water ordering is not sufficient to explain INPs' high ice-nucleation activity and confirm that intact three-dimensional protein structures are critical for bacterial ice nucleation, supporting a mechanism that depends on the INPs' supramolecular interactions.

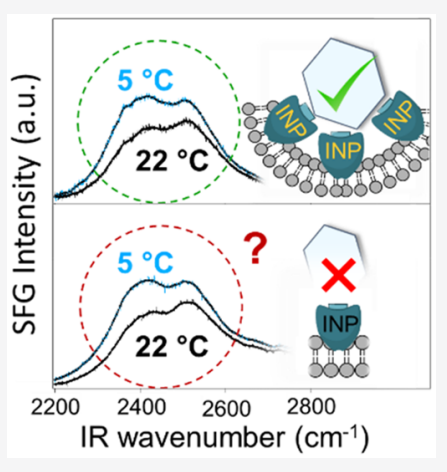

$\mathrm{T}$ he formation of ice is thermodynamically favored in water at temperatures below $0{ }^{\circ} \mathrm{C}$, but the crystallization is kinetically hindered owing to the energy barrier associated with creating the initial ice seed. ${ }^{1}$ As a result, pure water droplets can, depending on their size and cooling rate, be supercooled to temperatures as low as $-38{ }^{\circ} \mathrm{C}$. ${ }^{2}$ Ice crystals can be formed either by homogeneous nucleation at lower temperatures or by heterogeneous nucleation catalyzed by compounds that serve as ice nucleators (IN). The most effective biological IN known are ice-nucleating proteins from bacteria such as Pseudomonas syringae. ${ }^{3,4}$ Bacterial INPs can have different sizes but are typically large macromolecules that are anchored to the outer cell membrane of the bacterial cell wall. They are typically present as monomers but have repeatedly been shown to aggregate in the bacterial outer membranes. ${ }^{5-8}$ Large INP aggregates are thought to be responsible for freezing at temperatures between -2 and $-4{ }^{\circ} \mathrm{C}$ and smaller INP aggregates at temperatures between -7 and $-12{ }^{\circ} \mathrm{C}$.

Computer-based homology modeling proposed the bacterial INP structure to be $\beta$-helical (Figure 1A) with similarities to hyperactive insect antifreeze proteins (AFPs). ${ }^{10}$ More recent models based on molecular dynamic simulations further suggest that a highly conserved threonine-X-threonine motif is used to interact with ice, which again is similar to some AFPs. ${ }^{11}$ On the molecular scale, the INPs are believed to work by organizing water into preordered patterns, which increase in size as the temperature decreases until they are large enough to form a stable embryonic crystal, leading to ice growth. ${ }^{12}$ However, the role of the INP structure, the interaction of INPs with water, and the underlying working mechanism remain largely unknown. Here, we study the effects of temperature on the structure, hydration shell, and ice-nucleation efficiency of purified proteinaceous IN of $P$. syringae.

We performed purification of fragmented $P$. syringae (Snomax) solutions using falling water ice affinity and rotary ice-shell purification (see the Supporting Information (SI) for details). ${ }^{13,14}$ Both purification methods use the unique property of the INPs to interact with ice and have previously been used to purify AFPs from natural sources. ${ }^{15}$ The purification process involved the incorporation of the INPs into the slowly growing ice phase and the exclusion of other biomolecules and impurities. Using this ice-affinity purification, we obtained a mixture of all the INPs present in P. syringae, including residual protein-associated lipids. The success of the purification was assessed by determining the ice-nucleation activity of the purified INPs using the high-throughput Twinplate Ice Nucleation Assay (TINA) (Figure 1 and Figure S2). ${ }^{16}$ In the following, we will refer to these purified samples as "purified INPs".

Figure 1B shows typical statistical freezing curves of aqueous solutions of fragmented $P$. syringae and purified INPs with $0.1 \mathrm{mg} / \mathrm{mL}$, while Figure $1 \mathrm{C}$ compares their freezing behaviors inferred from freezing curves recorded for concentrations spanning from $0.1 \mathrm{mg} / \mathrm{mL}$ to $1 \mathrm{ng} / \mathrm{mL}$ (see also Figure S3).

Received: October 19, 2020

Accepted: December 3, 2020

Published: December 16, 2020 


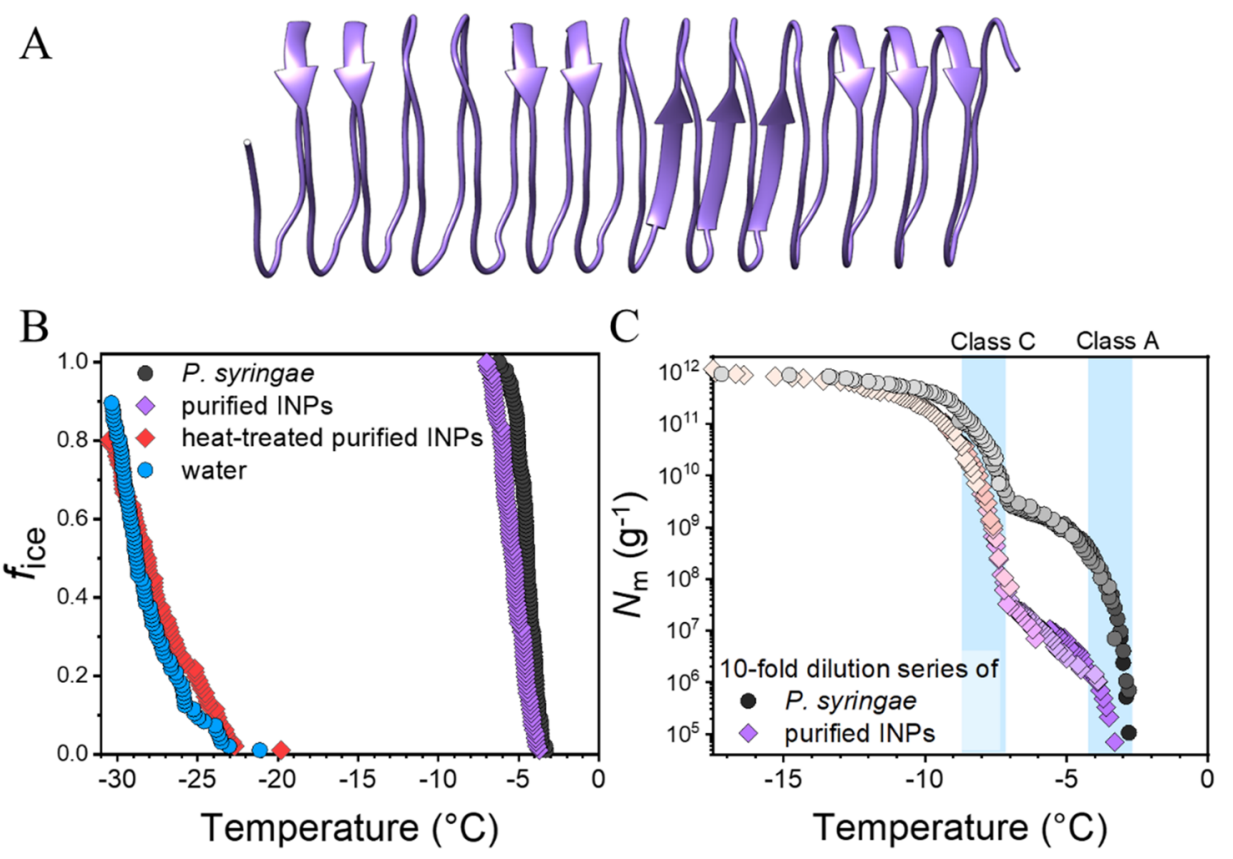

Figure 1. Structure and ice-nucleation activity of the proteinaceous ice nucleators from P. syringae. (A) Model structure of the INP from P. syringae, possessing a $\beta$-helical fold. (B) Statistical freezing curves of aqueous $P$. syringae solutions and their purified INPs, compared to the heat-inactivated INPs and the freezing curve of pure water in our system. Shown is the fraction of frozen $3 \mu \mathrm{L}$ droplets $\left(f_{\text {ice }}\right)$ vs temperature for the highest concentrations $(0.1 \mathrm{mg} / \mathrm{mL})$ of the utilized dilution series. (C) Freezing spectra of aqueous dilutions $\left(10^{-1} \mathrm{mg} / \mathrm{mL}\right.$ to $\left.10^{-6} \mathrm{mg} / \mathrm{mL}\right)$ of $P$. syringae and their purified INPs. Shown are the cumulative numbers of active IN $\left(N_{\mathrm{m}}\right)$ per unit mass vs temperature. The temperature ranges for class A and class $\mathrm{C}$ bacterial IN in water are shaded in blue.

The curve of $P$. syringae shows two substantial increases in the cumulative number of IN per unit mass, $N_{\mathrm{m}}(T)$ (Figure 1C) around -3.0 and $-7.5^{\circ} \mathrm{C}$ with plateaus between -4.5 and $-7.0^{\circ} \mathrm{C}$ and below $-9.5{ }^{\circ} \mathrm{C}$. At the plateaus, at temperatures below each increase of $N_{\mathrm{m}}(T)$, fewer IN are active. ${ }^{17}$ The two rises in the curve reveal that the ice-nucleation activity stems from two distinct classes of IN with different activation temperatures. We attribute the observed rise at $-3.0{ }^{\circ} \mathrm{C}$ to large assemblies of INPs (class A IN) and the rise at $-7.5^{\circ} \mathrm{C}$ to smaller assemblies of INPs (class C IN) in accordance with previous studies. ${ }^{18-23}$ The freezing curve of the purified INPs looks similar to the nonpurified INP solution, with a change in the ratio of the INP number in the two classes at -3.0 and $-7.5{ }^{\circ} \mathrm{C}$ (see also Figure S2). Clearly, the purification process was successful and yielded active INPs. The reduction of class A IN activity for the purified sample indicates that the purification reduced the number of the larger INP aggregates compared to the nonpurified solution. This observation is in line with the hypothesis that the bacterial membranes are involved in the formation of larger functional INP aggregates, ${ }^{5,10,24-28}$ and we expect bacterial membrane fragments to have no ice affinity.

Heat-treated INP solutions (see the SI for details on heat treatment) behave fundamentally differently. As apparent from comparing the droplet freezing statistics of the highest dilution concentrations shown in Figure 1B, the rises at -3.0 and -7.5 ${ }^{\circ} \mathrm{C}$ are completely absent. Instead, we observe activity only around $-25^{\circ} \mathrm{C}$, which corresponds to background freezing of pure water in our system. Evidently, the heat treatment of the purified INPs completely inactivates their ice-nucleation abilities.

Using SFG spectroscopy, Pandey et al. reported that fragmented $P$. syringae bacteria (Snomax) show an increased capability to order water in their vicinity when cooled to temperatures close to the melting point of deuterated water. ${ }^{29}$ Control experiments using misfolded and denatured INP fragments, lipids, and the protein lysozyme did not show this effect. The alignment of water into an ordered structure was concluded to be a condition that will promote interfacial ice nucleation.

Here, we conducted further SFG experiments with active and heat-inactivated INPs to determine whether there is a direct causal correlation between enhanced SFG water signals at low temperatures and bacterial ice-nucleation activity. In SFG, a broadband infrared pulse resonant with the probed molecular vibrations and a visible pulse are combined at a surface to generate light at the sum frequency of the two incident fields. The SFG process is bulk-forbidden in isotropic media, and only ensembles of molecules with a net orientation, e.g., at an interface, can generate a detectable signal.

Figure 2A shows the temperature-dependent SFG spectra of aqueous solutions of purified INPs. The broad response from the $\mathrm{O}-\mathrm{D}$ stretching bands of interfacial water molecules appears at frequencies below $2700 \mathrm{~cm}^{-1}$ and is affected by their interactions with the INPs adsorbed to the air-liquid interface. In the frequency region of $2800-3000 \mathrm{~cm}^{-1}$, the SFG spectra show strong signals that we attribute to $\mathrm{C}-\mathrm{H}$ stretching vibrations.

The SFG intensity of the $\mathrm{O}-\mathrm{D}$ bands strongly increases upon lowering the temperature close to the melting temperature $\left(3.82{ }^{\circ} \mathrm{C}\right.$ for $\left.\mathrm{D}_{2} \mathrm{O}\right)$, indicating an increase in the structural order of the interfacial water molecules. This effect is completely reversible, as evident from the integrals of the water (O-D) bands for two cycles shown in the insets. The observed effect is also significantly larger than the effect observed for pure water (insets in Figure 2 and Figure S4). ${ }^{30}$ In contrast, the signal intensity of the $\mathrm{C}-\mathrm{H}$ stretching vibrations remains constant upon lowering the temperature. 

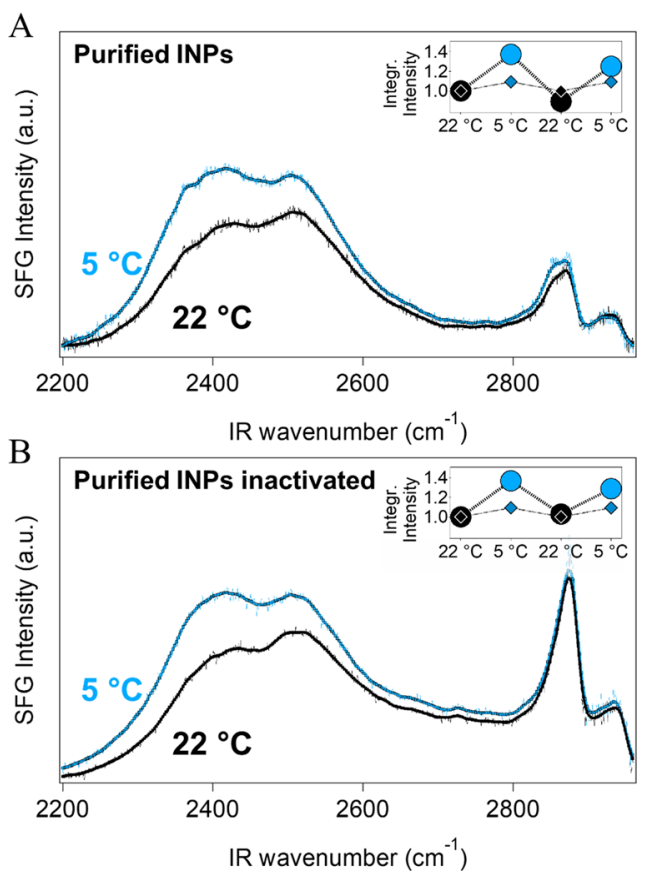

Figure 2. Temperature-dependent SFG measurements of aqueous solutions of active and heat-inactivated proteinaceous ice nucleators purified from $P$. syringae. (A) SFG spectra of the active INPs at the air-liquid interface in $\mathrm{D}_{2} \mathrm{O}$ at 22 and $5{ }^{\circ} \mathrm{C}$, respectively. (B) SFG spectra of the heat-inactivated INPs at the air-liquid interface in $\mathrm{D}_{2} \mathrm{O}$ at 22 and $5{ }^{\circ} \mathrm{C}$, respectively. The bulk INP concentrations were 0.1 $\mathrm{mg} / \mathrm{mL}$. The insets show the integrated SFG intensities in the O-D stretching frequency region of $\sim 2200-2700 \mathrm{~cm}^{-1}$ for two temperature cycles (circles) compared to pure $\mathrm{D}_{2} \mathrm{O}$ (squares), normalized to the respective first value at $22{ }^{\circ} \mathrm{C}$.

Figure 2B shows temperature-dependent SFG spectra of aqueous solutions of heat-inactivated INPs. Interestingly, we find that the completely inactive INPs adsorbed to the airliquid interface cause a comparably strong increase in the SFG intensity of the $\mathrm{O}-\mathrm{D}$ signals upon lowering the temperature. Thus, we conclude that the enhanced interfacial water ordering at low temperatures cannot be directly associated with the presence of ice-nucleation active sites.

Interestingly, while the water response is indistinguishable between the active and inactivated INPs, marked changes occur in the $\mathrm{C}-\mathrm{H}$ stretching region. Although we cannot precisely assign the manifold $\mathrm{C}-\mathrm{H}$ stretching contributions in the SFG spectra, these changes indicate that there is a substantial change in the protein structure after inactivation.

Figure 3A shows SFG spectra in the amide I region, which is sensitive to the secondary structure and orientation of proteins. $^{31,32}$ The amide I SFG spectra at room temperature and close to the melting temperature look very similar and show a strong signal at $\sim 1645 \mathrm{~cm}^{-1}$ and a weak signal at $\sim 1710 \mathrm{~cm}^{-1}$. We assign the signal at $1645 \mathrm{~cm}^{-1}$ to the protein backbone of the INPs ${ }^{33-35}$ and the weak signal at $1710 \mathrm{~cm}^{-1}$ to carbonyl groups in lipid molecules (see also Figure S5). ${ }^{36-38}$ The lipid signal presumably originates from membrane lipids that remain protein-associated during the purification, which is in line with the presence of class A aggregates in our freezing experiments (Figure 1B). The observation that the amide I SFG spectra do not change upon cooling suggests no structural or conformational changes of the INPs upon approaching biologically relevant working temperatures. These conclusions
A

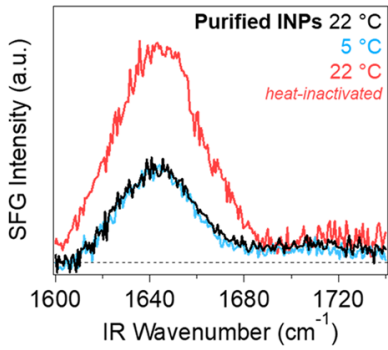

$\mathrm{B}$

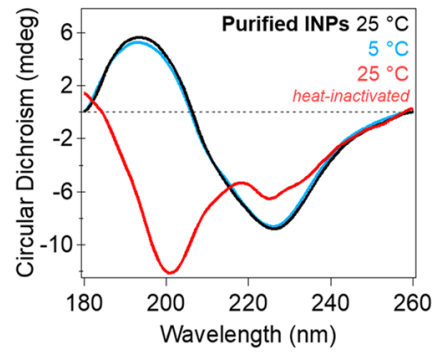

Figure 3. Amide I SFG and CD spectra of purified INPs derived from P. syringae. (A) SFG spectra of purified INPs in $\mathrm{D}_{2} \mathrm{O}$, measured in the amide I region. The spectra of the active INP at 22 and $5{ }^{\circ} \mathrm{C}$ look similar, with signals at $\sim 1640$ and $1710 \mathrm{~cm}^{-1}$. The heat-inactivated INPs (red) show a considerably increased signal at $\sim 1640 \mathrm{~cm}^{-1}$. (B) $\mathrm{CD}$ spectra of purified INPs in water at 25 and $5{ }^{\circ} \mathrm{C}$, as well as at 25 ${ }^{\circ} \mathrm{C}$ after heat-inactivation (red). Dashed lines indicate zero in both panels.

are supported by temperature-dependent CD spectra that also show very little change upon lowering the temperature (Figure 3B).

Upon heating of the purified INPs, the amide I SFG response and the $\mathrm{CD}$ spectrum undergo marked changes, as evident from Figures $3 \mathrm{~A}$ and $3 \mathrm{~B}$. Figure $3 \mathrm{~A}$ shows that the interfacial protein backbone SFG signal at $\sim 1645 \mathrm{~cm}^{-1}$ of heatinactivated INPs is increased, while the lipid signal at $\sim 1710 \mathrm{~cm}^{-1}$ appears unaffected. The CD spectrum of the active INPs in Figure 3B shows a maximum molar ellipticity at $195 \mathrm{~nm}$ and a minimum at $228 \mathrm{~nm}$, after which there is a gradual return to zero from 230 to $260 \mathrm{~nm}$. Increasing the temperature reduces the molar ellipticity at $195 \mathrm{~nm}$, and the minimum at $228 \mathrm{~nm}$ is reduced (see also Figure S7). These spectral changes following heating above $\sim 55{ }^{\circ} \mathrm{C}$ suggest significant, irreversible alterations in the secondary structure contents of the INPs. We propose that the observed irreversible conformational changes cause a loss of the proteins' native functional structure and are the origin of the complete elimination of the INP's ice-nucleation activity after heat treatment.

The CD spectrum of the purified INPs (Figure 4A) looks unusual, and its deconvolution using the structural database does not allow a clear distinction into the common secondary structures of $\alpha$-helix, $\beta$-turn, $\beta$-strand, or random coil. ${ }^{41}$ The spectral shape, however, shows similarities with those of AFPs derived from Marinomonas primoryensis (MpAFP) and Rhagium inquisitor (RiAFP) (Figure 4B, 4C) but with slightly shifted peak positions. Both AFPs have $\beta$-helical folds, ${ }^{41}$ which is in agreement with the current theoretical model of the INP as shown in Figure $1 \mathrm{~A}$ and the inset of Figure $4 \mathrm{~A} .{ }^{42}$ The negligible changes in $\mathrm{CD}$ spectra at low temperatures are further consistent with temperature-dependent measurements of structurally similar $\beta$-helical AFPs. ${ }^{43}$

In summary, we purified INPs from $P$. syringae using iceaffinity methods and report experimental evidence that the purified INPs are ice-nucleation active and that they adopt defined solution structures, which show resemblance with $\beta$ helical AFP spectra. $^{41}$ We further show that enhanced interfacial water ordering at temperatures close to the melting point of ice is found not only for active but also for completely inactivated INPs. While protein-induced enhanced interfacial water ordering likely constitutes an essential part of INPs' 
A

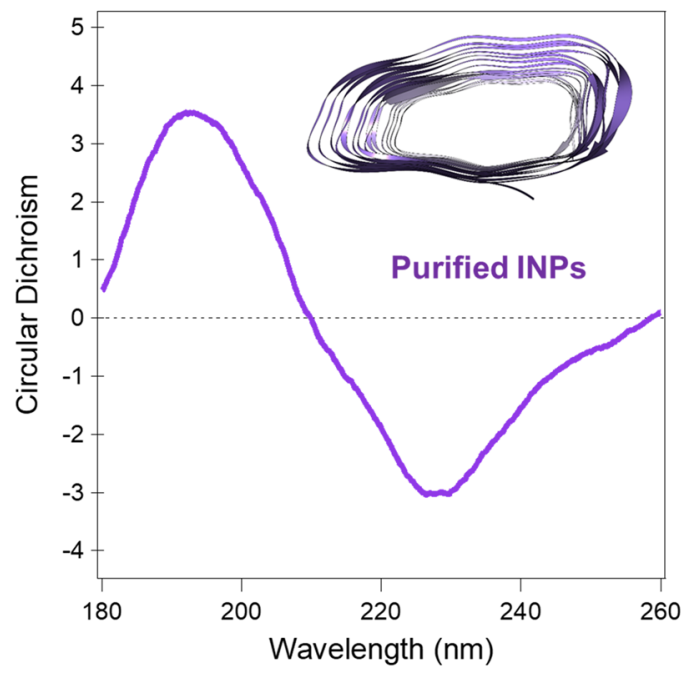

$\mathrm{B}$
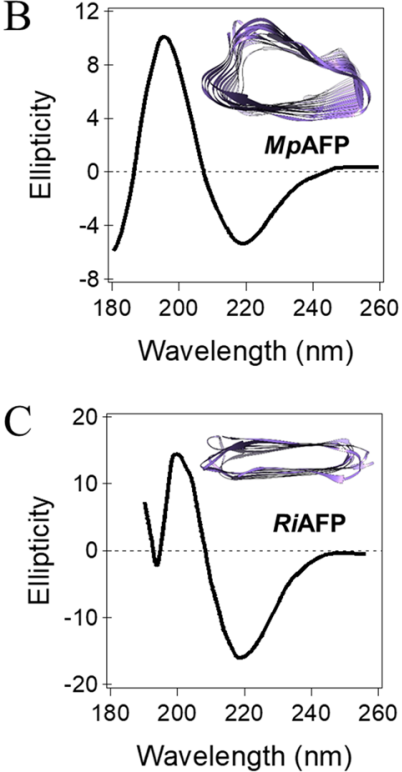

Figure 4. Circular dichroism spectrum of purified INPs compared to the spectra of two AFPs. (A) CD spectra of purified INPs derived from fragmented P. syringae at $25{ }^{\circ} \mathrm{C}$ in water [circular dichroism (mdeg)]. (B) CD spectrum of an AFP derived from Marinomonas primoryensis (MpAFP) [ellipticity (mdeg)]. Data obtained from Garnham et al. ${ }^{39}$ (C) CD spectrum of an AFP derived from Rhagium inquisitor (RiAFP) [mean residue ellipticity $\left.\left(\mathrm{deg} \mathrm{cm}^{-2} / \mathrm{dmol} \times 10^{-3}\right)\right]$. Data obtained from Hakim et al. ${ }^{40}$ Dashed lines indicate zero in all panels. The insets show cross sections of the proteins with the $\beta$-sheets highlighted in purple.

working mechanism, our results reveal that increased water ordering observed with SFG spectroscopy is, by itself, not a sufficient condition for INP activity. Instead, our results highlight that the intact three-dimensional fold is essential for the ice-nucleation activity of INPs. This observation, combined with the similarity of the protein structure of the INPs from $P$. syringae and other ice-binding proteins, suggests that supramolecular interactions and ordering are key to the exceptional ice-nucleation activity of bacterial INPs. ${ }^{42}$ We hypothesize that the completely intact native structure of the INP is required for the formation of the functional aggregates that allow the formation of ice nuclei or embryos large enough to enable freezing at $-2{ }^{\circ} \mathrm{C}\left(\sim 10^{4} \mathrm{kDa}\right){ }^{23-25}$ Specifically, if the observed water ordering effect plays a role in bacterial ice nucleation, we can surmise that some secondary structures of the INPs remain at least partially intact, inducing a similar degree of order. However, the breakdown of higher-order structures (tertiary, quaternary) leads to the loss of the collective alignment of INP units that explains the substantial loss in effectiveness. ${ }^{24}$ This hypothesis would predict a freezing behavior of the inactivated INPs comparable to structurally similar antifreeze proteins and will be tested in future studies.

\section{ASSOCIATED CONTENT}

\section{S1 Supporting Information}

The Supporting Information is available free of charge at https://pubs.acs.org/doi/10.1021/acs.jpclett.0c03163.

Experimental details, experimental methods, and supporting Figures S1-S7: Coomassie blue-stained SDS PAGE analysis of ice-affinity purifications of the INPs; freezing experiments of aqueous solutions of $P$. syringae (A) and purified INPs (B); fraction of frozen droplets for $P$. syringae and purified INP solutions corresponding to data shown in Figure 1; temperature-dependent sumfrequency generation measurements of pure $\mathrm{D}_{2} \mathrm{O}$ at 22 and $5{ }^{\circ} \mathrm{C}$; SFG spectra in the amide I region; SFG spectra of Snomax (gray) and purified INPs (black) as well as inactive INPs (red); CD spectra of purified INPs derived from $P$. syringae at temperatures from 25 to 75 ${ }^{\circ} \mathrm{C}$ in water as well as an autoclaved sample $\left(121^{\circ} \mathrm{C}\right)$ (A), and the melting curve of the protein obtained from the circular dichroism values at $222 \mathrm{~nm}$ (B); and CD spectra of purified INPs and fragmented $P$. syringae (Snomax), normalized to the highest local maximum, respectively (PDF)

\section{AUTHOR INFORMATION}

\section{Corresponding Authors}

Max Lukas - Max Planck Institute for Polymer Research, 55128 Mainz, Germany; 이이.org/0000-0001-69498423; Email: lukas@mpip-mainz.mpg.de

Konrad Meister - Max Planck Institute for Polymer Research, 55128 Mainz, Germany; University of Alaska Southeast, Juneau, Alaska 99801, United States; orcid.org/00000002-6853-6325; Email: meisterk@mpip-mainz.mpg.de

\section{Authors}

Ralph Schwidetzky - Max Planck Institute for Polymer Research, 55128 Mainz, Germany

Anna T. Kunert - Max Planck Institute for Chemistry, 55128 Mainz, Germany

Ellen H.G. Backus - Max Planck Institute for Polymer Research, 55128 Mainz, Germany; Department of Physical Chemistry, University of Vienna, 1090 Vienna, Austria; (1) orcid.org/0000-0002-6202-0280

Ulrich Pöschl - Max Planck Institute for Chemistry, 55128 Mainz, Germany; @ orcid.org/0000-0003-1412-3557

Janine Fröhlich-Nowoisky - Max Planck Institute for Chemistry, 55128 Mainz, Germany; (i) orcid.org/00000002-1278-0054 
Mischa Bonn - Max Planck Institute for Polymer Research, 55128 Mainz, Germany; 이이.org/0000-0001-68518453

Complete contact information is available at:

https://pubs.acs.org/10.1021/acs.jpclett.0c03163

\section{Author Contributions}

${ }^{\perp}$ These authors contributed equally.

\section{Notes}

The authors declare no competing financial interest.

\section{ACKNOWLEDGMENTS}

We are grateful to the MaxWater initiative from the Max Planck Society and the Max Planck Graduate Center with the Johannes Gutenberg University Mainz (MPGC) for financial support. The authors would like to thank David Ng and Sabine Pütz for help with the CD spectroscopy and gel electrophoreses experiments.

\section{REFERENCES}

(1) Murray, B. J.; Broadley, S. L.; Wilson, T. W.; Bull, S. J.; Wills, R. H.; Christenson, H. K.; Murray, E. J. Kinetics of the Homogeneous Freezing of Water. Phys. Chem. Chem. Phys. 2010, 12 (35), 1038010387.

(2) Koop, T.; Luo, B.; Tsias, A.; Peter, T. Water Activity as the Determinant for Homogeneous Ice Nucleation in Aqueous Solutions. Nature 2000, 406 (6796), 611-614.

(3) Kozloff, L. M.; Schofield, M. A.; Lute, M. Ice Nucleating Activity of Pseudomonas Syringae and Erwinia Herbicola. J. Bacteriol. 1983, 153 (1), 222-231.

(4) Maki, L. R.; Galyan, E. L.; Chang-Chien, M.-M.; Caldwell, D. R. Ice Nucleation Induced by Pseudomonas Syringae1. Appl. Microbiol. 1974, 28 (3), 456-459.

(5) Govindarajan, A. G.; Lindow, S. E. Size of Bacterial IceNucleation Sites Measured in Situ by Radiation Inactivation Analysis. Proc. Natl. Acad. Sci. U. S. A. 1988, 85, 1334.

(6) Southworth, M. W.; Wolber, P. K.; Warren, G. J. Nonlinear Relationship between Concentration and Activity of a Bacterial Ice Nucleation Protein. J. Biol. Chem. 1988, 263 (29), 15211-15216.

(7) Mueller, G. M.; Wolber, P. K.; Warren, G. J. J. C. Clustering of Ice Nucleation Protein Correlates with Ice Nucleation Activity. Cryobiology 1990, 27 (4), 416-422.

(8) Schmid, D.; Pridmore, D.; Capitani, G.; Battistutta, R.; Neeser, J. R.; Jann, A. Molecular Organisation of the Ice Nucleation Protein Inav from Pseudomonas Syringae. FEBS Lett. 1997, 414 (3), 590594.

(9) Turner, M. A.; Arellano, F.; Kozloff, L. M. Three Separate Classes of Bacterial Ice Nucleation Structures. J. Bacteriol. 1990, 172 (5), 2521-2526.

(10) Garnham, C. P.; Campbell, R. L.; Walker, V. K.; Davies, P. L. Novel Dimeric Beta-Helical Model of an Ice Nucleation Protein with Bridged Active Sites. BMC Struct. Biol. 2011, 11 (1), 36.

(11) Hudait, A.; Moberg, D. R.; Qiu, Y.; Odendahl, N.; Paesani, F.; Molinero, V. Preordering of Water Is Not Needed for Ice Recognition by Hyperactive Antifreeze Proteins. Proc. Natl. Acad. Sci. U. S. A. 2018, 115 (33), 8266-8271.

(12) Duman, J. G. Antifreeze and Ice Nucleator Proteins in Terrestrial Arthropods. Annu. Rev. Physiol. 2001, 63 (1), 327-357.

(13) Adar, C.; Sirotinskaya, V.; Bar Dolev, M.; Friehmann, T.; Braslavsky, I. Falling Water Ice Affinity Purification of Ice-Binding Proteins. Sci. Rep. 2018, 8 (1), 11046.

(14) Marshall, C. J.; Basu, K.; Davies, P. L. Ice-Shell Purification of Ice-Binding Proteins. Cryobiology 2016, 72 (3), 258-263.

(15) Tomalty, H. E.; Graham, L. A.; Eves, R.; Gruneberg, A. K.; Davies, P. L. Laboratory-Scale Isolation of Insect Antifreeze Protein for Cryobiology. Biomolecules 2019, 9 (5), 180.
(16) Kunert, A. T.; Lamneck, M.; Helleis, F.; Pöschl, U.; Pohlker, M. L.; Fröhlich-Nowoisky, J. Twin-Plate Ice Nucleation Assay (Tina) with Infrared Detection for High-Throughput Droplet Freezing Experiments with Biological Ice Nuclei in Laboratory and Field Samples. Atmos. Meas. Tech. 2018, 11 (11), 6327-6337.

(17) Budke, C.; Koop, T. Binary: An Optical Freezing Array for Assessing Temperature and Time Dependence of Heterogeneous Ice Nucleation. Atmos. Meas. Tech. 2015, 8 (2), 689-703.

(18) Maki, L. R.; Galyan, E. L.; Chang-Chien, M. M.; Caldwell, D. R. Ice Nucleation Induced by Pseudomonas Syringae. Appl. Microbiol. 1974, 28 (3), 456-459.

(19) Yankofsky, S. A.; Levin, Z.; Bertold, T.; Sandlerman, N. Some Basic Characteristics of Bacterial Freezing Nuclei. J. Appl. Meteorol. 1981, 20 (9), 1013-1019.

(20) Turner, M. A.; Arellano, F.; Kozloff, L. M. Three Separate Classes of Bacterial Ice Nucleation Structures. J. Bacteriol. 1990, 172 (5), 2521-2526.

(21) Kozloff, L. M.; Turner, M. A.; Arellano, F. Formation of Bacterial Membrane Ice-Nucleating Lipoglycoprotein Complexes. J. Bacteriol. 1991, 173 (20), 6528-6536.

(22) Schwidetzky, R.; Kunert, A. T.; Bonn, M.; Pöschl, U.; Ramløv, H.; DeVries, A. L.; Fröhlich-Nowoisky, J.; Meister, K. Inhibition of Bacterial Ice Nucleators Is Not an Intrinsic Property of Antifreeze Proteins. J. Phys. Chem. B 2020, 124 (24), 4889-4895.

(23) Lukas, M.; Schwidetzky, R.; Kunert, A. T.; Pöschl, U.; FröhlichNowoisky, J.; Bonn, M.; Meister, K. Electrostatic Interactions Control the Functionality of Bacterial Ice Nucleators. J. Am. Chem. Soc. 2020, 142 (15), 6842-6846.

(24) Qiu, Y.; Hudait, A.; Molinero, V. How Size and Aggregation of Ice-Binding Proteins Control Their Ice Nucleation Efficiency. J. Am. Chem. Soc. 2019, 141 (18), 7439-7452.

(25) Pummer, B. G.; Budke, C.; Augustin-Bauditz, S.; Niedermeier, D.; Felgitsch, L.; Kampf, C. J.; Huber, R. G.; Liedl, K. R.; Loerting, T.; Moschen, T.; et al. Ice Nucleation by Water-Soluble Macromolecules. Atmos. Chem. Phys. 2015, 15 (8), 4077-4091.

(26) Ling, M. L.; Wex, H.; Grawe, S.; Jakobsson, J.; Londahl, J.; Hartmann, S.; Finster, K.; Boesen, T.; Santl-Temkiv, T. Effects of Ice Nucleation Protein Repeat Number and Oligomerization Level on Ice Nucleation Activity. J. Geophys. Res.: Atmos. 2018, 123 (3), 18021810.

(27) Bonechi, C.; Tamasi, G.; Pardini, A.; Donati, A.; Volpi, V.; Leone, G.; Consumi, M.; Magnani, A.; Rossi, C. Ordering Effect of Protein Surfaces on Water Dynamics: Nmr Relaxation Study. Biophys. Chem. 2019, 249, 106149.

(28) Burke, M. J.; Lindow, S. E. Surface-Properties and Size of the Ice Nucleation Site in Ice Nucleation Active Bacteria - Theoretical Considerations. Cryobiology 1990, 27 (1), 80-84.

(29) Pandey, R.; Usui, K.; Livingstone, R. A.; Fischer, S. A.; Pfaendtner, J.; Backus, E. H.; Nagata, Y.; Fröhlich-Nowoisky, J.; Schmuser, L.; Mauri, S.; et al. Ice-Nucleating Bacteria Control the Order and Dynamics of Interfacial Water. Sci. Adv. 2016, 2 (4), No. e1501630.

(30) Moberg, D. R.; Straight, S. C.; Paesani, F. Temperature Dependence of the Air/Water Interface Revealed by Polarization Sensitive Sum-Frequency Generation Spectroscopy. J. Phys. Chem. B 2018, 122 (15), 4356-4365.

(31) Meister, K.; Roeters, S. J.; Paananen, A.; Woutersen, S.; Versluis, J.; Szilvay, G. R.; Bakker, H. J. Observation of Ph-Induced Protein Reorientation at the Water Surface. J. Phys. Chem. Lett. 2017, 8 (8), 1772-1776.

(32) Roeters, S. J.; van Dijk, C. N.; Torres-Knoop, A.; Backus, E. H.; Campen, R. K.; Bonn, M.; Woutersen, S. Determining in Situ Protein Conformation and Orientation from the Amide-I Sum-Frequency Generation Spectrum: Theory and Experiment. J. Phys. Chem. A 2013, 117 (29), 6311-6322.

(33) Fu, L.; Wang, Z.; Psciuk, B. T.; Xiao, D.; Batista, V. S.; Yan, E. C. Characterization of Parallel Beta-Sheets at Interfaces by Chiral Sum Frequency Generation Spectroscopy. J. Phys. Chem. Lett. 2015, 6 (8), 1310-1315. 
(34) Chen, X.; Wang, J.; Sniadecki, J. J.; Even, M. A.; Chen, Z. Probing Alpha-Helical and Beta-Sheet Structures of Peptides at Solid/ Liquid Interfaces with Sfg. Langmuir 2005, 21 (7), 2662-2664.

(35) Golbek, T. W.; Franz, J.; Elliott Fowler, J.; Schilke, K. F.; Weidner, T.; Baio, J. E. Identifying the Selectivity of Antimicrobial Peptides to Cell Membranes by Sum Frequency Generation Spectroscopy. Biointerphases 2017, 12 (2), $02 \mathrm{D} 406$.

(36) Dreier, L. B.; Bonn, M.; Backus, E. H. G. Hydration and Orientation of Carbonyl Groups in Oppositely Charged Lipid Monolayers on Water. J. Phys. Chem. B 2019, 123 (5), 1085-1089.

(37) Blume, A.; Hubner, W.; Messner, G. Fourier Transform Infrared Spectroscopy of $13 \mathrm{c}=$ O-Labeled Phospholipids Hydrogen Bonding to Carbonyl Groups. Biochemistry 1988, 27 (21), 82398249.

(38) Mantsch, H. H.; Mcelhaney, R. N. Phospholipid PhaseTransitions in Model and Biological-Membranes as Studied by Infrared-Spectroscopy. Chem. Phys. Lipids 1991, 57 (2-3), 213-226.

(39) Garnham, C. P.; Gilbert, J. A.; Hartman, C. P.; Campbell, R. L.; Laybourn-Parry, J.; Davies, P. L. A Ca2+-Dependent Bacterial Antifreeze Protein Domain Has a Novel Beta-Helical Ice-Binding Fold. Biochem. J. 2008, 411 (1), 171.

(40) Hakim, A.; Thakral, D.; Zhu, D. F.; Nguyen, J. B. Expression, Purification, Crystallization and Preliminary Crystallographic Studies of Rhagium Inquisitor Antifreeze Protein. Acta Crystallogr., Sect. F: Struct. Biol. Cryst. Commun. 2012, 68 (5), 547-550.

(41) Basu, K.; Graham, L. A.; Campbell, R. L.; Davies, P. L. Flies Expand the Repertoire of Protein Structures That Bind Ice. Proc. Natl. Acad. Sci. U. S. A. 2015, 112 (3), 737-742.

(42) Hudait, A.; Odendahl, N.; Qiu, Y.; Paesani, F.; Molinero, V. Ice-Nucleating and Antifreeze Proteins Recognize Ice through a Diversity of Anchored Clathrate and Ice-Like Motifs. J. Am. Chem. Soc. 2018, 140 (14), 4905-4912.

(43) Li, N.; Kendrick, B. S.; Manning, M. C.; Carpenter, J. F.; Duman, J. G. Secondary Structure of Antifreeze Proteins from Overwintering Larvae of the Beetle Dendroides Canadensis. Arch. Biochem. Biophys. 1998, 360 (1), 25-32. 